\title{
Gelem Takon: Strategi Menjadikan Sekolah Cerdas Karakter
}

\author{
lis Nur'aeni \\ SMPN 12 Kota Cirebon \\ tehiiskng123@gmail.com
}

\section{Article History}

accepted 01/12/2020

published 01/03/2021

\begin{abstract}
Gelem Takon's strategy in good practice is inspired by the scientific approach in K-13, namely the "ask" stage which is a description of curiosity. Gelem Takon also resembles a Cirebonlanguage phrase which means "want to ask". In the context of this good practice, Gelem Takon is an acronym that contains the managerial pattern strategy adopted by the principal. The Gelem Takon strategy consists of two complementary implementation processes. The GELEM strategy is a strategy to improve human resources in schools which consists of five stages, namely: (1) Be active in setting an example; (2) empathy and care for the environment; (3) Be more disciplined and diligent; (4) Energy to develop potential; and (5) Motivation is enhanced. The strategy is then combined with the role and function of the principal as school manager, namely the TAKON strategy: (1) Ask and understand; (2) Adaptive to change; (3) Creative and innovative; (4) Orientation on quality improvement; and (5) Real for the progress of schools. The conclusions from the implementation of the Gelem Takon strategy at SMPN 12 Cirebon are: (1) The Gelem Takon strategy has been successful and implemented as expected. This can be seen in 90\% of the implementation and achievement of school programs; (2) The impact of implementing the Gelem Takon strategy is realized by achieving various achievements and increasing public trust in schools.
\end{abstract}

Keywords: Strategy, gelem takon, intelligent, character

\begin{abstract}
Abstrak
Strategi Gelem Takon dalam dalam praktik baik ini terinspirasi dari pendekatan saintifik dalam K-13 yaitu tahapan "bertanya" yang merupakan gambaran rasa ingin tahu. Gelem Takon juga yang menyerupai sebuah frasa berbahasa Cirebon yang bermakna "mau bertanya". Dalam konteks praktik baik ini, Gelem Takon adalah akronim yang berisi strategi pola manajerial yang diterapkan kepala sekolah. Strategi Gelem Takon terdiri dari dua proses implementasi yang saling melengkapi. Strategi GELEM adalah strategi peningkatan SDM di sekolah yang terdiri dari lima tahapan yaitu: (1) Giat memberi teladan; (2) Empati dan peduli pada lingkungan; (3) Lebih disiplin dan rajin; (4) Energi untuk mengembangkan potensi; dan (5) Motivasi ditingkatkan. Strategi tersebut kemudian dipadukan dengan peran dan fungsi kepala sekolah sebagai manajer sekolah yaitu strategi TAKON: (1) Tanyakan dan pahami; (2) Adaptif pada perubahan; (3) Kreatif dan inovatif; (4) Orientasi pada peningkatan mutu; dan (5) Nyata bagi kemajuan sekolah. Simpulan dari penerapan strategi Gelem Takon di SMPN 12 Kota Cirebon adalah: (1) Strategi Gelem Takon telah berhasil dan terlaksana sesuai harapan. Hal ini tampak pada 90\% keterlaksanaan dan ketercapaian program sekolah; (2) Dampak implementasi strategi Gelem Takon terwujud dengan diraihnya berbagai prestasi dan meningkatnya kepercayaan masyarakat terhadap sekolah.
\end{abstract}

Kata kunci: Strategi, gelem takon, cerdas, karakter

Social, Humanities, and Education Studies (SHEs): Conference Series https://jurnal.uns.ac.id/shes

p-ISSN 2620-9284

e-ISSN 2620-9292 


\section{PENDAHULUAN}

Kemudahan mengakses media digital sangat menguntungkan bagi pembelajaran jika dimanfaatkan secara tepat. Hal inilah yang perlu dikuatkan oleh guru dalam proses pembelajaran dan kegiatan pembiasaan di sekolah. Hal tersebut menjadi fokus perhatian penulis bukanlah tanpa alasan. Selain karena tantangan di era digital, sekolah ini pun semula merupakan sekolah yang memiliki branding (citra publik) yang negatif. Sejauh pengamatan dan wawancara yang dilakukan oleh penulis terhadap warga sekitar, SMPN 12 Kota Cirebon dikenal sebagai tempat sekolahnya anak-anak yang nakal, sulit diatur dan "jago" tawuran.

Kedisiplinan dan tingkat kehadiran siswa maupun guru sangat rendah. Sebagian besar tembok di ruang-ruang kelas kotor dengan sampah dan penuh coretan kata-kata kasar. Cara berpakaian dan berpenampilan siswa pun dibiarkan urakan. Siswa dan sekolah sangat minim prestasi dalam berbagai lomba yang digelar baik di tingkat kabupaten kota maupun ajang lomba di tingkat lebih tinggi.

Selain pembiasaan dalam menanamkan karakter tidak berjalan dengan baik, faktor yang membuat sekolah ini lebih terpuruk adalah kurang optimalnya kompetensi guru dalam implementasi Kurikulum 2013. Sejatinya, para guru sudah dapat menerapkan pembelajaran 4C (communication, critical thinking, collaborative and creativity) serta pembelajaran berbasis HOTS (high order thinking skills). Namun kenyatannya belum semua guru melaksanakan kegiatan pembelajaran seperti yang diharapkan.

Selain itu, budaya membaca guru sangat rendah, penguasaan terhadap modelmodel pembelajaran aktif juga belum cukup variatif. Keterbatasan kemampuan guru dalam menggunakan perangkat TIK juga menambah daftar panjang tantangan guru dalam memberikan layanan pembelajaran bagi peserta didik. Budaya belajar guru, minat baca guru masih rendah, rasa ingin tahu terhadap hal-hal baru pun masih kurang.

Oleh karena itu, penulis melakukan sebuah upaya untuk memperbaiki citra publik terhadap SMPN 12 Kota Cirebon melalui sebuah strategi. Strategi ini diperlukan untuk membangkitkan motivasi, rasa percaya diri, tanggung jawab, serta kepedulian semua warga sekolah untuk mengubah sekolah menjadi lebih baik.

Strategi yang dilakukan penulis diberi nama GELEM TAKON. Strategi ini terinspirasi dari pendekatan saintifik dalam K-13 yaitu tahapan "menanya" atau "bertanya" yang merupakan sebuah aktivitas gambaran rasa ingin tahu serta pro-aktif. GELEM TAKON merupakan akronim yang menyerupai sebuah frasa berbahasa Cirebon yang bermakna "mau bertanya". Namun GELEM TAKON dalam konteks praktik baik ini adalah sebuah akronim yang berisi strategi adaptasi dari berbagai pola manajerial yang harus dimiliki kepala sekolah.

Tujuan penyusunan best practice ini adalah mengetahui proses dan dampak implementasi strategi Gelem Takon dalam upaya mengubah citra sekolah menjadi sekolah berkarakter pemelajar. Adapun manfaat yang diharapkan dari hasil penulisan praktik baik (best practice) ini adalah: (1) memberikan kontribusi positif bagi ketercapaian visi dan misi sekolah; (2) terciptanya budaya mutu yang dapat mengubah citra sekolah; (3) meningkatkan minat pengembangan kompetensi guru; (4) membangun karakter postif melalui keterampilan literasi.

\section{HASIL DAN PEMBAHASAN}

Dalam bahasa Cirebon gelem bermakna mau, sedangkan takon artinya bertanya, jadi jika diartikan sesuai bahasa asalnya gelem takon bermakna "mau bertanya". Selain makna asal dari bahasa Cirebon yang diuraikan di atas, GELEM TAKON merupakan sebuah akronim dari strategi manajerial yang akan dilaksanakan oleh penulis di sekolah. 
Strategi ini secara substasi merujuk pada beberapa teori manajemen sekolah seperti MBS (manajemen berbasis sekolah) dan konsep kepemimpinan TQM (total quality management). Strategi GELEM ini terdiri dari 5 tahapan yaitu: (1) Giat memberikan teladan; (2) Empati dan peduli pada lingkungan; (3) Lebih disiplin dan rajin; (4) Energi untuk mengembangkan potensi; dan (5) Motivasi ditingkatkan.

Strategi tersebut kemudian dipadukan dengan peran dan fungsi kepala sekolah sebagai manajer yaitu strategi TAKON: (1) Tanyakan dan pahami; (2) Adaptif pada perubahan; (3) Kreatif dan inovatif; (4) Orientasi pada peningkatan mutu; dan (5) Nyata bagi kemajuan sekolah.

Selain alasan makna kebahasaan yang mencirikan sisi rasa ingin tahu dan makna akronim yang mengarah pada perbaikan manajerial, strategi GELEM TAKON dipilih penulis karena juga mengandung makna filosofis kearifan lokal masyarakat Cirebon. Kekentalan budaya cirebon yang tercermin dalam bahasa dan budaya menjadi aset penting yang harus terus diasah dan bersinergi dengan dunia pendidikan.

Penguatan Pendidikan Karakter (PPK) termaktub dalam Permendikbud Nomor 20 Tahun 2018 Tentang Penguatan Pendidikan Karakter Pada Satuan Pendidikan Formal. Dalam Permendikbud tersebut dinyatakan bahwa PPK adalah gerakan pendidikan di bawah tanggung jawab satuan pendidikan formal untuk memperkuat karakter peserta didik melalui harmonisasi olah hati, olah rasa, olah pikir, dan olah raga dengan pelibatan serta kerja sama antara satuan pendidikan, keluarga, dan masyarakat sebagai bagian dari Gerakan nasional Revolusi Mental (GNRM). Berdasarkan uraian tersebut dapat disimpulkan bahwa karakter adalah sifat serta perilaku positif yang ditanamkan hingga berubah menjadi suatu kebiasaan atau budaya baik.

Oleh karena itulah, sekolah sebagai pengemban amanat implementasi PPK sudah sepatutnya menjadi organisasi yang dapat mewujudkan penguatan karakter baik termasuk karakter pemelajar. Lebih lanjut diuraikan ada 5 dimensi disiplin belajar yang harus ada dalam sebuah organisasi pemelajar. Kelima disiplin ini merupakan unsur yang mempengaruhi terciptanya organisasi pembelajaran.

1. Berpikir sistem (system thinking), yaitu merupakan suatu cara berpikir untuk menguraikan dan memahami kekuatan-kekuatan dan hubungan antarpribadi yang membentuk perilaku sistem, berpikir sistem ini intinya harus memandang organisasi sebagai suatu sistem yang utuh.

2. Penguasaan pribadi (personal mastery), merupakan disiplin belajar untuk meningkatkan kapasitas pribadi, untuk menciptakan hasil yang diinginkan dan menciptakan lingkungan organisasi yang mendorong semua anggota untuk mencapai tujuan yang telah dipilihnya. Dengan penguasan diri yang baik, individu akan mengetahui apa yang harus dilakukan.

3. Model mental (mental models), merupakan disiplin belajar yang terus menerus melakukan perenungan, mengklasifikasi, memperbaiki gambaran-gambaran internal kita tentang dunia dan melihat bagaimana hal itu membentuk tindakan dan keputusan. Mental model ini sangat berhubungan dengan konsep diri yang akan menghasilkan cara berpikir atau mindset.

4. Membangun visi bersama (shared vision), merupakan disiplin untuk membangun komitmen dalam kelompok, membuat gambaran gambaran atau mimpi-mimpi bersama tentang masa depan yang ingin dicapai, serta prinsipprinsip dan praktekpraktek penuntun yang akan digunakan dalam mencapai masa depan itu.

5. Pembelajaran tim (team learning), merupakan disiplin untuk mengembangkan kecerdasan dan keahlian para anggota secara tim sehingga menjadi lebih besar lagi dari pada pengembangan secara individual. 
Manajemen partisipatif menurut Mulyasa (2012) adalah bahwa dalam pendekatan berbasis mutu, kepemimpinan di sekolah tergantung pada pemberdayaan para guru dan staf lain yang terlibat dalam proses belajar mengajar. Untuk mencapai hal tersebut seorang pemimpin harus memiliki komitmen yang kuat dalam meningkatkan mutu, memimpin inovasi, membangun tim yang kreatif, mengawasi, serta mengevaluasi keberhasilan.

Berdasarkan konsep tersebut, maka implementasi strategi Gelem Takon dideskripsikan dalam lima tahapan strategi peningkatan mutu SDM yang dipadukan dengan lima tahapan peran dan fungsi kepala sekolah.

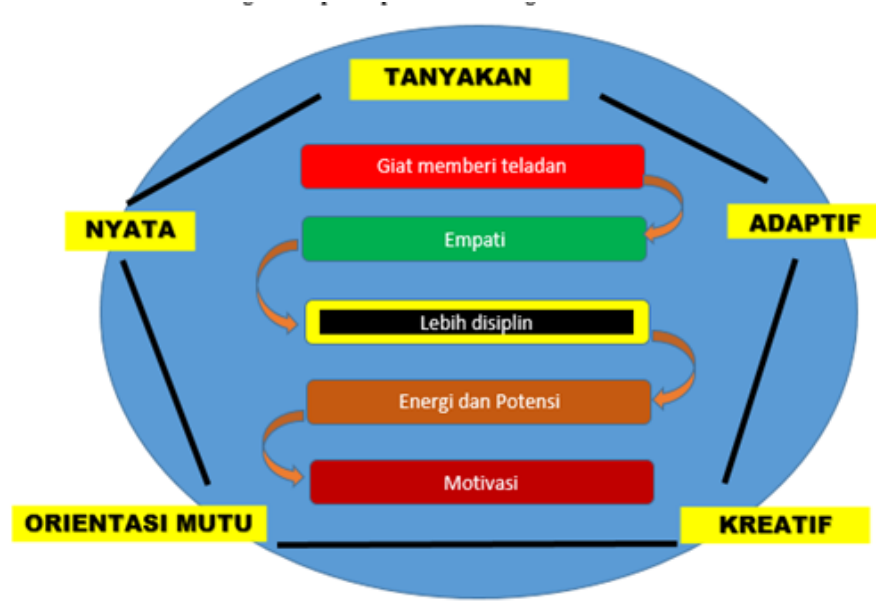

\section{Gambar 1. Tahapan Strategi Gelem Takon}

Strategi GELEM TAKON terdiri dari dua proses implementasi yang saling melengkapi. Strategi GELEM adalah strategi peningkatan SDM di sekolah yang terdiri dari lima tahapan yaitu: (1) Giat memberi teladan; (2) Empati dan peduli pada lingkungan; (3) Lebih disiplin dan rajin; (4) Energi untuk mengembangkan potensi; dan (5) Motivasi ditingkatkan.

Strategi tersebut kemudian dipadukan dengan peran dan fungsi kepala sekolah sebagai manajer sekolah yaitu strategi TAKON: (1) Tanyakan dan pahami; (2) Adaptif pada perubahan; (3) Kreatif dan inovatif; (4) Orientasi pada peningkatan mutu; dan (5) Nyata bagi kemajuan sekolah.

Implementasi strategi tersebut diuraikan dalam indikator dan rencana aksi yaitu: (1) Menyusun indikator dan rencana aksi implementasi strategi GELEM TAKON; (2) Melaksanakan strategi GELEM TAKON dalam setiap perencanaan dan pelaksanaan program sekolah; (3) Menentukan instrumen capaian strategi GELEM TAKON; (4) Melakukan refleksi, evaluasi, pemantauan dan tindak lanjut pada setiap program sekolah.

Tabel 1. Indikator dan Rencana Aksi Strategi GELEM TAKON

\begin{tabular}{|c|c|c|c|c|}
\hline No & Strategi & Indikator & Rencana Aksi & $\begin{array}{c}\text { Peran Kepala } \\
\text { Sekolah }\end{array}$ \\
\hline 1 & $\begin{array}{l}\text { Giat memberi } \\
\text { teladan }\end{array}$ & - Keteladanan & $\begin{array}{l}\text { - Melaksanakan nilai- } \\
\text { nilai PPK dalam } \\
\text { semua kegiatan } \\
\text { sekolah. }\end{array}$ & $\begin{array}{l}>\text { Tanyakan dan } \\
\text { pahami } \\
>\text { Adaptif pada } \\
\text { perubahan } \\
>\text { Kreatif dan }\end{array}$ \\
\hline
\end{tabular}


SHEs: Conference Series 4 (2) (2021) 88- 87

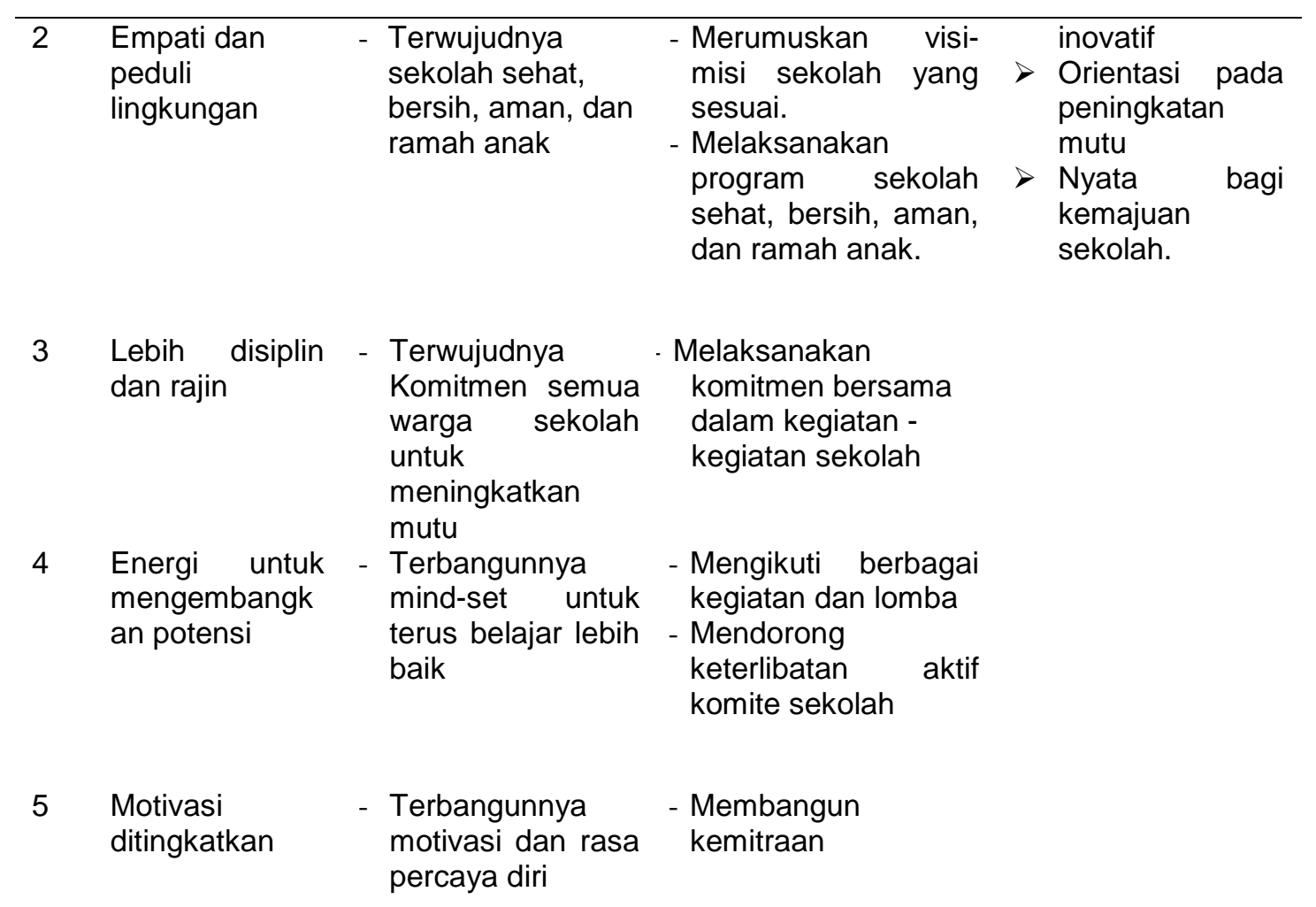

A. Hasil dan Dampak yang Dicapai

Berikut ini adalah hasil yang diperoleh setelah menggunakan strategi Gelem Takon di SMPN 12 Kota Cirebon.

1) Ketercapaian Program

Tabel 2. Ketercapaian Indikator Program

\begin{tabular}{|c|c|c|c|}
\hline No & Indikator & Keterlaksanaan & Ketercapaian \\
\hline 1 & Keteladanan & 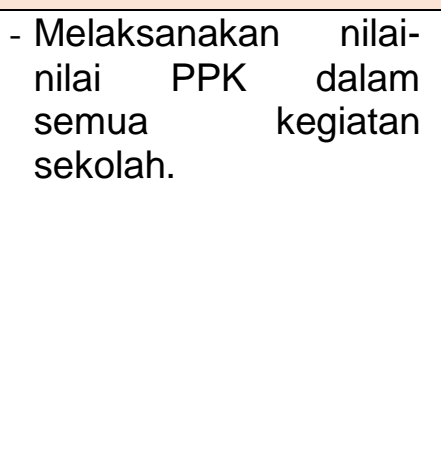 & $\begin{array}{l}\text { - SMPN } 12 \text { Kota Cirebon } \\
\text { ditetapkan sebagai } \\
\text { sekolah Model Rintisan } \\
\text { PPK oleh Dinas } \\
\text { Pendidikan dan Puskur } \\
\text { Kemdikbud } \\
\text { - Guru bersama-sama } \\
\text { peserta didik } \\
\text { melaksanakan kegiatan } \\
\text { berbasis PPK }\end{array}$ \\
\hline 2 & $\begin{array}{l}\text { Terwujudnya } \\
\text { sekolah sehat, } \\
\text { bersih, aman, } \\
\text { dan ramah anak }\end{array}$ & $\begin{array}{l}\text { - Tersusunnya visi-misi } \\
\text { sekolah yang sesuai } \\
\text { dengan rencana } \\
\text { pengembangan } \\
\text { sekolah } \\
\text { - Melaksanakan } \\
\text { berbagai program } \\
\text { kegiatan sekolah } \\
\text { sehat, bersih, aman, }\end{array}$ & $\begin{array}{l}\text { - Visi dan Misi SMPN } 12 \\
\text { Cirebon "Bersahabat" } \\
\text { dan "Cetar Cemerlang" } \\
\text { telah mampu memberi } \\
\text { sugesti positif sehingga } \\
\text { citra buruk sekolah } \\
\text { hilang. } \\
\text { - Juara II Sekolah } \\
\text { Adiwiyata Tingkat Kota }\end{array}$ \\
\hline
\end{tabular}


SHEs: Conference Series 4 (2) (2021) 88-87

\begin{tabular}{|c|c|c|c|}
\hline & & dan ramah anak. & $\begin{array}{l}\text { Cirebon. } \\
\text { - Sekolah Adiwiyata } \\
\text { Tingkat Provinsi Jawa } \\
\text { Barat } \\
\text { - Juara } 1 \text { Lomba Wajah } \\
\text { Bahasa Sekolah Tingkat } \\
\text { Provinsi Jabar. } \\
\text { - Kepala SMP Inspiratif } \\
\text { tingkat Nasional } 2020 .\end{array}$ \\
\hline 3 & $\begin{array}{l}\text { Terwujudnya } \\
\text { Komitmen } \\
\text { semua warga } \\
\text { sekolah untuk } \\
\text { meningkatkan } \\
\text { mutu }\end{array}$ & $\begin{array}{l}\text { - Terbentuknya Tim } \\
\text { Pengembang } \\
\text { Kurikulum } \\
\text { - Terbentuknya tim } \\
\text { Penjaminan Mutu } \\
\text { Internal sekolah } \\
\text { - Terbentuknya unit-unit } \\
\text { tim kegiatan program } \\
\text { sekolah lainnya }\end{array}$ & $\begin{array}{l}\text { - Guru melaksanakan } \\
\text { MGMP sekolah } \\
\text { - Guru menyusun } \\
\text { perangkat pembelajaran } \\
\text { dengan baik. } \\
\text { - Terlaksananya berbagai } \\
\text { kegiatan melalui } \\
\text { kerjasama tim. }\end{array}$ \\
\hline 4 & $\begin{array}{l}\text { Terbangunnya } \\
\text { mind-set untuk } \\
\text { terus belajar } \\
\text { lebih baik }\end{array}$ & $\begin{array}{l}\text { - Ikut serta dalam } \\
\text { berbagai kegiatan dan } \\
\text { lomba siswa, guru, } \\
\text { dan TU. } \\
\text { - Terbentuknya komite } \\
\text { sekolah yang baru } \\
\text { dan keterlibatan aktif } \\
\text { dalam program } \\
\text { kegiatan sekolah. }\end{array}$ & $\begin{array}{l}\text { - Terlaksananya UNBK } \\
\text { Mandiri. } \\
\text { - Meraih berbagai prestasi } \\
\text { dalam lomba. } \\
\text { - Guru proaktif mengikuti } \\
\text { berbagai kegiatan } \\
\text { pengembangan } \\
\text { kompetensi baik yang } \\
\text { diadakan sekolah } \\
\text { maupun mandiri. } \\
\text { - Komite proaktif dalam } \\
\text { bantuan material. }\end{array}$ \\
\hline 5 & $\begin{array}{l}\text { Terbangunnya } \\
\text { motivasi dan } \\
\text { rasa percaya diri }\end{array}$ & $\begin{array}{l}\text { - Menjalin kemitraan } \\
\text { dengan berbagai } \\
\text { lembaga dan dunia } \\
\text { usaha }\end{array}$ & $\begin{array}{l}\text { - Mengikuti berbagai } \\
\text { kegiatan akademik } \\
\text { maupun sosial di luar } \\
\text { sekolah. } \\
\text { - Terlaksananya kegiatan } \\
\text { motivation day yang } \\
\text { menambah rasa percaya } \\
\text { diri warga sekolah } \\
\text { karena banyak } \\
\text { dikunjungi oleh berbagai } \\
\text { tokoh dan profesi. }\end{array}$ \\
\hline
\end{tabular}

2) Dampak terhadap Prestasi 
SHEs: Conference Series 4 (2) (2021) 88-87

Tabel 3. Prestasi Sekolah

\begin{tabular}{|c|c|c|}
\hline No & Tahun & Prestasi yang Diraih \\
\hline 1 & 2018 & $\begin{array}{l}\text { Sekolah Rintisan Model Penguatan } \\
\text { Karakter Puskur, Balitbang Kemdikbud }\end{array}$ \\
\hline 2 & 2019 & Juara II Lomba Sekolah Adiwiyata Kota Cirebon \\
\hline 3 & 2020 & Sekolah Adiwiyata Tingkat Provinsi jawa Barat \\
\hline 4 & 2020 & $\begin{array}{l}\text { Juara } 1 \text { Lomba Wajah Bahasa Sekolah Tingkat } \\
\text { Provinsi Jawa Barat }\end{array}$ \\
\hline 5 & 2020 & Kepala SMP Inspiratif Tingkat Nasional 2020 \\
\hline
\end{tabular}

\section{SIMPULAN}

Simpulan dari penerapan strategi GELEM TAKON di SMPN 12 Kota Cirebon adalah: (1) Strategi GELEM TAKON telah berhasil dan terlaksana sesuai harapan. Hal ini tampak pada $90 \%$ keterlaksanaan dan ketercapaian program sekolah; (2) Dampak implementasi strategi GELEM TAKON terwujud dengan diraihnya berbagai prestasi dan meningkatnya kepercayaan masyarakat terhadap sekolah.

\section{DAFTAR PUSTAKA}

Apandi, Idris. (2019). Kepala Sekolah Kreatif dan Inovatif di Era Revolusi Industri 4.0. Yogyakarta: Samudera Biru.

Direktorat Pembinaan Tendik, Dirjen GTK, Kemdikbud. (2015). Bunga Rampai Karya Tulis Kepala Sekolah Berprestasi dan Berdedikasi Tahun 2015. Jakarta: Kemdikbud.

Hendrawati, Sri. (2017). Strategi Ambu dalam Membangun Warung Literasi di Sekolah Dasar Negeri 166 Ciateul Kota Bandung Tahun 2015-2017. Jakarta:

Kemdikbud. Naskah Simposium Kepala Sekolah dan Pengawas Tingkat Nasional, tidak dipublikasikan.

Kemdikbud. (2016). Permendikbud Nomor 28 Tahun 2016 tentang Sistem Penjaminan Mutu Pendidikan (SPMP) Dasar dan Menengah.

Kemdikbud. (2018). Permendikbud Nomor 6 Tahun 2018 tentang Penugasan Guru Sebagai Kepala Sekolah.

Kemdikbud. (2018). Permendikbud Nomor 20 Tahun 2018 Tentang Penguatan Pendidikan Karakter Pada Satuan Pendidikan Formal.

Mulyasa. (2011). Manajemen Berbasis Sekolah: Konsep, Strategi, dan Implementasi. Bandung: Remaja Rosda Karya.

Mulyasa. (2012). Manajemen dan Kepemimpinan Kepala Sekolah. Jakarta: Bumi Aksara.

Rokayana, Hamidah. (2019). Best Practice : Praktik Baik SMPN 1 Pante Bidari Kabupaten Aceh Timur. Bandung: Goebuk Senja Pustaka. 